\title{
Development of Ready to Eat Buffalo Meat Product using Tapioca Flour
}

\author{
S. Karthikeyan, V. Appa Rao, R. Narendra Babu and S. Karthika* \\ Department of Livestock Products Technology (Meat Science), \\ Madras Veterinary College, Puddukottai, India \\ *Corresponding author
}

\section{A B S T R A C T}

Keywords

Buffalo meat,

Fracturability,

Sensory evaluation

and Tapioca powder

\section{Article Info}

Accepted:

17 September 2019

Available Online:

10 October 2019
Buffaloes are a potential source of nutritionally high quality meat. Buffalo meat is the healthiest meat among red meats known for human consumption. In order to improve the palatability of the buffalo meat a value added meat extruded product was developed using the tapioca flour as a binder. Hence a study was conducted to found the quality characteristics of buffalo meat extruded product using tapioca flour in three different proportions viz., 15:85, 25:75 and 35:65. The Physico-Chemical characteristics such as Cooking Yield, Expansion Ratio, Bulk Density, Water Absorption Index, Water Solubility Index were significantly higher in 15:85 proportions compared to other two and Sensory Evaluation were also found to be better in 15:85 proportions. Hence it is stored at ambient temperature for three months and subjected to further analysis such as physico-chemical characteristics (viz. pH, thiobarbituric acid no. tyrosine value, hardness and fracturability) and sensory analysis on every fort night interval during the storage period of three months. There was a significant increase in the thiobarbituric acid no. tyrosine value and hardness throughout the storage period but no significant difference were found in sensory evaluation hence it could be concluded that tapioca powder can be included in buffalo meat extruded product in 15:85 proportion.

\section{Introduction}

The Food and Agricultural Organization (FAO, 2008) has termed buffalo as an important asset that is "undervalued." Meat produced from buffaloes has gained increased popularity in several south eastern and middleeastern Asian countries and Africa because of its reduced fat, reduced cholesterol, and other healthier attributes. In terms of buffalo production and population, India is the most important place in the world. With more than $50 \%$ of the buffaloes in the world, India has become the largest bovine meat exporter. Buffalo meat does not possess any religious taboo against its consumption, is emerging as important red meat source, and is gaining popularity in many parts of the world. India produced 1.53 million tonnes (MT) of buffalo meat of which 1.1 MT were exported to more 
than 48 countries around the world (APEDA, 2014). India overtook Brazil as the top bovine meat exporter (boneless frozen meat) in the world, and Indian buffalo meat exports are expected to increase by $20 \%$ to $1.7 \mathrm{MT}$ because of competitive pricing and quality. A small proportion of buffalo meat is domestically consumed in India as hot-boned boneless meat without chilling or any further processing. China (including mainland China) produces 0.62 MT of buffalo meat, most of which is sold as fresh meat and only small proportion of which is processed into dried meat, sausages, and ham. Hence a new initiative was taken to develop ready to eat extruded meat snacks out of buffalo meat.

Extrusion cooking is a relatively recent form of food processing. Forcing material through a hole is the process of extrusion. Sausage extruders were developed in the nineteenth century as simple forming machines. Eventually pasta was produced in extruders. Flour and water were added at one end of the machine, and a screw mixed and compressed the dough before extruding it through numerous holes or dies that gave the pasta its shape. During the 1930s heat was added to the barrel containing the screw; puffed corn curl snacks resulted. The pressure developed as the dough moved along the screw; this, together with the heat under pressure, caused the corn to puff upon exiting the dies. As extrusion cooking processed more types of food, extruders became more specialized for food applications. Twin-screw extruders containing two screws were adapted from the polymer industry, and these machines are considerably more versatile than the single screw extruders. Extruded products are often subjected to further processing, such as frying, baking, and rolling (Camire, 2002). Extrusion can produce safe, lightweight, shelf-stable foods that can be stored for use during famines and natural disasters. Many opportunities exist for product development research in extrusion.
The present study was aimed at developing the ready to eat snacks with protein rich flour using extrusion technology and further evaluating the shelf life of the developed products and also evaluate the effect of ambient storage on the quality characteristics of ready to eat snacks incorporated with optimum levels of tapioca flours.

\section{Materials and Methods}

Buffalo meat procured from Corporation Slaughter house, Perambur, Chennai - 12 was utilized for this study. The purchased meat was packed hygienically and brought to the Department of Meat Science and Technology, Madras Veterinary College, Chennai - 7. Fat and connective tissue were removed manually. The buffalo meat was cut into small pieces and then minced in a meat mincer using $4.5 \mathrm{~mm}$ plate. The minced meat was then dried in hot air oven at $100^{\circ} \mathrm{C}$ for two hours and subsequently at $80^{\circ} \mathrm{C}$ for $12-14$ hours and finally made into a powder. The buffalo meat powder obtained was sieved to get refined meat powder. The refined meat powder was packed in polyethylene packaging materials until used (Table 1).

\section{Extruded buffalo meat product formulation}

Extruded meat product was formulated with buffalo meat in combination with plant binders constituting 100 per cent of the formulation and above various additives was added. The formulation is described below

\section{Preparation of buffalo meat extruded product}

The buffalo meat powder and respective flours were taken to the Department of Food and Agricultural Process Engineering, Agricultural Engineering and Research Institute, Coimbatore. The buffalo meat powder and tapioca flour along with other ingredients were mixed thoroughly was passed through 
U.S.No.14 sieve. To this mixture 10\% (V/W) water was added and packed in polyethylene bags and allowed to equilibrate for one hour.

\section{Extrusion cooking}

Six batches of extruded products were prepared by incorporating buffalo meat powder and tapioca flour in proportions of $15: 85,25: 75$ and 35:65 respectively along with minor ingredients as additives. The preconditioned mix of raw material was fed into the twin screw extruder at $95^{\circ} \mathrm{C}$ for $1-2$ minutes and thus extrudates were prepared. Expanded extrudates were air dried at room temperature $\left(37^{\circ} \mathrm{C}\right)$. The dried extrudates were cut into small pieces (approximately $10 \mathrm{~cm}$ in length) and deep fried in oil and immediately subjected to sensory evaluation to select the optimum proportion of buffalo meat powder and tapioca flour. Then the selected optimum proportion of buffalo meat powder and tapioca flour were packed in polyethylene bags and stored at room temperature $\left(37^{0} \mathrm{C}\right)$ until further analysis.

\section{Cooking yield (Per Cent)}

The weight of buffalo meat extruded products were recorded just before cooking and immediately after cooking from which the cooking yield was calculated between the difference of product after cooking and before cooking.

\section{Hardness and fracturability by texture analyser}

Hardness ( $\mathrm{g}$ ) and fracturability $(\mathrm{mm})$ of the dry extrudates was determined from the peak of the displacement plot of the extrudate during shearing in a Texture Analyzer (Stable Micro Systems - TA-HDi, Surrey, England) using a Warner-Bratzler blade (Kharagpur, West Bengal, India). The cross head pre test speed, test speed and post test speed were $1.00,0.50$ and $5.00 \mathrm{~mm} / \mathrm{min}$, respectively. The full load scale was $5 \mathrm{~kg}$ depending on the hardness of the extrudates. The shear blade used was $1.22 \mathrm{~mm}$ thick with a shear angle of $90^{\circ}$. Single extrudate cylinders placed in the cell were sheared into two pieces by the shear blade and the maximum force registered during shearing was recorded.

\section{Water Absorption Index (WAI)}

The water absorption index was measured according to the method described by Bryant et al., (2001). 2.5g of ground sample was suspended in $30 \mathrm{ml}$ of distilled water $\left(30^{\circ} \mathrm{C}\right)$ in a $50 \mathrm{ml}$ preweighed centrifuge tube. The tubes were placed in a $30^{\circ} \mathrm{C}$ water bath and intermittently stirred for $30 \mathrm{~min}$. the suspension was centrifuged for $10 \mathrm{~min}$ at $3,000 \mathrm{X} \mathrm{g}$ and the supernatant was decanted into a preweighed $50 \mathrm{ml}$ beaker. The weight of the precipitate was used to calculate the WAI which was reported as a ratio (weight gain/ weight of sample).

\section{Water Solubility Index (WSI)}

The supernatant liquid obtained from water absorption index determination used for determination of water solubility index. The supernatant liquid collected in the preweighed $50 \mathrm{ml}$ beaker was kept in a hot air oven $\left(95^{\circ} \mathrm{C}\right)$ to evaporate to dryness. After drying, the beakers were cooled and weighed. The water solubility index was calculated as weight of dried solids to initial weight of the sample and expressed in $\%$.

\section{Bulk density}

Bulk density of snack foods was determined based on the procedure described by Choudhury and Gautam (2003). Bulk density was estimated by determining the mass and apparent volume of individual dry, cylindrical extruded rods (5 to $10 \mathrm{~cm}$ long). Apparent volume was calculated as the product of length and cross-section area of the extruded 
rods. Five extrudate cylinders were randomly selected from each sample. Ten diameters and five lengths were measured at different points on each cylinder. The average values for five extrudate cylinders were used for calculation of apparent volume of each sample. Bulk density was calculated by dividing the mass by volume.

\section{Thiobarbituric Acid Number (TBA)}

Twenty gram of samples was blended in the laboratory blender with $50 \mathrm{ml}$ of cold 20 per cent Trichloroacetic acid for two minutes. The blended contents were rinsed with $50 \mathrm{ml}$ of distilled water, mixed together and filtered through the filter paper (Whatman No.1, 18.5 $\mathrm{cm}$ diameter) and filtrate was collected in a $100 \mathrm{ml}$ capacity-measuring cylinder.

The filtrate termed the Trichloroacetic acid (TCA) extract was used in the estimation of TBA number and tyrosine value (TV). Thiobarbituric acid (TBA) number was measured by a modified method by Strange et al., (1977). 5ml of the TCA extract was mixed with $5 \mathrm{ml}$ of TBA reagent in a test tube. The test tube was kept in water bath at $100^{\circ} \mathrm{C}$ for $30 \mathrm{~min}$ along with a test tube containing a blank of $5 \mathrm{ml}$ of 10 percent TCA and $5 \mathrm{ml}$ of TBA reagent. After cooling the test tubes in running water for about 10 minutes, the developed colour was measured as absorbance at $530 \mathrm{~nm}$ in the spectrophotometer (UV-VIS spectrophotometer, ELICO, SL 164 Double beam) at medium sensitivity and reported as TBA number.

\section{Tyrosine value}

Tyrosine value was determined by the modified method of Strange et al., (1977). About $2.5 \mathrm{ml}$ of the TCA extract was diluted with equal quantity of distilled water in a test tube. To this, $10 \mathrm{ml}$ of $0.5 \mathrm{~N} \mathrm{NaOH}$ was added followed by $3 \mathrm{ml}$ of diluted Folin and Ciocalteu's phenol reagent (1 part Folin and
Ciocalteu's phenol reagent +2 parts distilled water). After mixing and keeping for 15 minutes at room temperature, the developed colour was measured as absorbance at $660 \mathrm{~nm}$ in the spectrophotometer (UV-VIS spectrophotometer, ELICO, SL 164 Double beam) at medium sensitivity, using a blank containing $5 \mathrm{ml}$ of diluted Folin and Ciocalteu's phenol reagent. By the reference to the standard graph, the tyrosine value was calculated as $\mathrm{mg}$ of tyrosine per $100 \mathrm{~g}$ of sample.

\section{Results and Discussion}

The buffalo meat extruded products were prepared by incorporating buffalo meat powder and tapioca flour in different proportions of 15:85, 25:75 and 35:65 respectively. The optimum level of inclusion of buffalo meat and tapioca flour was selected based on physico-chemical characteristics and sensory evaluation (Table 2-5).

\section{Physico-chemical characteristics}

\section{Cooking yield (per cent)}

The cooking yield was significantly $(\mathrm{P}<0.05)$ high in 15:85 (93.72 \pm 0.42$)$ proportion than the other two proportions of tapioca flour and there was no significant $(\mathrm{P}>0.05)$ difference between 25:75 (91.89 \pm 0.50$)$ and 35:65 $(91.59 \pm 0.67)$ proportions of tapioca flour.

The increase in cooking yield with increasing levels of tapioca flour may be due to the increase in starch content. Similarly, Venkatachalam (2009) stated that there was a significant increase in cooking yield as the proportion of chicken meat in the extruded product.

\section{Expansion ratio}

The expansion ratio was significantly $(\mathrm{P}<0.01)$ higher in 15:85 (5.45 \pm 0.91) and 25:75 (5.09 
$\pm 0.71)$ proportions than that of 35:65 (3.68 \pm $0.45)$ proportion. The expansion ratio decreased with decrease in the proportion of tapioca flour. The result was in agreement with the statement of Gogoi et al., (1996) in which only starch granules can participate in the formation of a stable expanded structure after gelatinization and Mohamed (1990) who mentioned that decrease in expansion ratio is because of the protein content which does not puff as that of starch.

\section{Bulk density}

No significant difference $(\mathrm{P}>0.05)$ was observed between the three different proportions of tapioca flour. But, Gogoi et al., (1996) stated that the extrudates with high protein content resulted in increased bulk density.

\section{Water absorption index}

The water absorption index was significantly $(\mathrm{P}<0.01)$ high in $15: 85 \quad(5.43 \pm 0.003)$ proportion than the other two proportions of tapioca flour and there was no significant $(\mathrm{P}>0.05)$ difference between 25:75 (3.82 \pm $0.002)$ and 35:65 (3.98 \pm 0.24$)$ proportions of tapioca flour. The results were similar to the findings of El-Samahy et al., (2007) in which there was a decrease in water absorption index due to the decreasing of starch.

\section{Water solubility index}

There was no significant $(\mathrm{P}>0.05)$ difference between the three different proportions of tapioca flour. The result was similar to the findings of Mittal and Lawrie (1984), where the water solubility index was not affected by the proportion of meat offals in the mixture.

\section{Sensory evaluation}

There was no significant $(\mathrm{P}>0.05)$ difference in the organoleptic scores for appearance, flavour, texture and saltiness between the three different proportions of tapioca flour.

There was no significant $(\mathrm{P}>0.05)$ difference in crispiness score between the 15:85 (5.41 \pm 0.11 ) and other two proportions of tapioca flour and significant $(\mathrm{P}<0.05)$ decrease in crispiness score was noticed in 35:65 (5.15 \pm $0.14)$ than $25: 75(5.70 \pm 0.07)$ proportion.

There was no significant $(\mathrm{P}>0.05)$ difference in overall acceptability scores between the 15:85 (5.42 \pm 0.08$)$ and other two proportions of tapioca flour and significant $(\mathrm{P}<0.05)$ decrease in overall acceptability score was noticed in 35:65 (5.14 \pm 0.09$)$ than $25: 75$ $(5.64 \pm 0.16)$ proportion. The result was in agreement with the findings of Jauregui et al., (2003) in which there was a tendency towards lower scores as more meat was added.

The results of Experiment II revealed that cooking yield, expansion ratio and water absorption index was significantly higher in 15:85 proportion of buffalo meat tapioca flour. Similarly, there was considerably improved crispiness and overall acceptability scores of sensory evaluation in 15:85 proportion. Hence, based on the above findings and cost economics the buffalo meat extruded product containing 15:85 proportion of buffalo meat powder and tapioca flour respectively was selected as optimum buffalo meat extruded product.

\section{Thiobarbituric Acid Number (TBA No)}

The mean \pm S.E values of thiobarbituric acid number of buffalo meat extruded product with optimum proportions of tapioca flour for 0 , $15,30,45,60,75$ and 90 days were $0.12 \pm$ $0.01,0.20 \pm 0.05,0.44 \pm 0.11,0.68 \pm 0.09$, $0.81 \pm 0.08,1.18 \pm 0.18$ and $1.37 \pm 0.23$ respectively. Analysis of variance revealed highly significant $(\mathrm{P}<0.01)$ difference of TBA No between storage periods which may be due to the lipid oxidation of the buffalo meat 
extruded product. The results were similar to the findings noticed by Anna Anandh et al., (2005) in which there was a significant increase in TBA No. through out the period of storage. Park et al., (1993) found a decrease in TBA value during the first 15 days of storage period and increased slowly thereafter.

\section{Tyrosine Value (TV)}

The mean \pm S.E values of tyrosine value of buffalo meat extruded product at optimum proportions of tapioca flour for $0,15,30,45$,
60,75 and 90 days were $0.88 \pm 0.12,0.99 \pm$ $0.05,1.38 \pm 0.13,1.39 \pm 0.10,1.53 \pm 0.12$, $1.62 \pm 0.13,1.73 \pm 0.11$ respectively. Analysis of variance revealed highly significant $(\mathrm{P}<0.01)$ difference of tyrosine value between storage periods.

The results were similar to the findings of Strange et al., (1977) in which they reported that the tyrosine value may be increased as bacterial load increased during the storage period (Table 4).

Table.1

\begin{tabular}{|c|c|c|c|c|}
\hline SI. No & Ingredients & \multicolumn{3}{|c|}{ Percentage w/w } \\
\hline 1 & Buffalo meat & 15 & 25 & 35 \\
\hline 2 & Plant binders (Tapioca flour) & 85 & 75 & 65 \\
\hline 3 & Sodium tri polyphosphate & 0.3 & 0.3 & 0.3 \\
\hline 4 & Salt & 2 & 2 & 2 \\
\hline 5 & Water & 12.5 & 12.5 & 12.5 \\
\hline 6 & Onion & 3 & 3 & 3 \\
\hline 7 & Garlic & 1 & 1 & 1 \\
\hline 8 & Sodium nitrite & $120 \mathrm{ppm}$ & $120 \mathrm{ppm}$ & $120 \mathrm{ppm}$ \\
\hline 9 & Water (V/W) & 10 & 10 & 10 \\
\hline
\end{tabular}

Table.2 Mean \pm SE values for Cooking yield (per cent), Expansion ratio, Bulk density, Water absorption index and Water solubility index of buffalo meat extruded product with different proportions of tapioca flour

\begin{tabular}{|c|c|c|c|c|c|}
\hline \multirow[t]{2}{*}{ Traits } & \multirow[t]{2}{*}{$\mathbf{n}$} & \multicolumn{3}{|c|}{$\begin{array}{c}\text { Different proportions of buffalo meat and } \\
\text { tapioca flour }\end{array}$} & \multirow[t]{2}{*}{ F-value } \\
\hline & & $15: 85$ & $25: 75$ & $35: 65$ & \\
\hline $\begin{array}{l}\text { Cooking Yield (per } \\
\text { cent) }\end{array}$ & 6 & $93.72^{b} \pm 0.42$ & $91.89^{\mathrm{a}} \pm 0.50$ & $91.59^{\mathrm{a}} \pm 0.67$ & $3.71^{*}$ \\
\hline Expansion ratio & 6 & $5.45^{b} \pm 0.91$ & $5.09^{b} \pm 0.71$ & $3.68^{a} \pm 0.45$ & $1.71^{\mathrm{NS}}$ \\
\hline Bulk density & 6 & $0.34^{\mathrm{a}} \pm 0.03$ & $0.26^{\mathrm{a}} \pm 0.04$ & $0.29^{\mathrm{a}} \pm 0.04$ & $1.54^{\mathrm{NS}}$ \\
\hline Water absorption index & 6 & $5.43^{b} \pm 0.003$ & $3.82^{\mathrm{a}} \pm 0.002$ & $3.98^{a} \pm 0.24$ & $39.15^{* *}$ \\
\hline Water solubility index & 6 & $17.79^{\mathrm{a}} \pm 1.42$ & $16.99^{\mathrm{a}} \pm 0.40$ & $18.71^{a} \pm 0.63$ & $0.44^{\mathrm{NS}}$ \\
\hline
\end{tabular}

Means bearing same superscript in a row do not differ significantly $(\mathrm{P}>0.05)$ 
Table.3 Mean \pm SE scores for sensory evaluation of buffalo meat extruded product with different proportions of tapioca flour

\begin{tabular}{|c|c|c|c|c|c|}
\hline \multirow{2}{*}{$\begin{array}{c}\text { Sensory } \\
\text { Attributes } \\
\text { score }\end{array}$} & \multirow[t]{2}{*}{$\mathbf{n}$} & \multicolumn{3}{|c|}{$\begin{array}{c}\text { Different proportions of buffalo meat and } \\
\text { tapioca flour }\end{array}$} & \multirow[t]{2}{*}{ F-value } \\
\hline & & $15: 85$ & $25: 75$ & $35: 65$ & \\
\hline Appearance & 6 & $5.74^{\mathrm{a}} \pm 0.20$ & $5.71^{\mathrm{a}} \pm 0.15$ & $5.45^{\mathrm{a}} \pm 0.18$ & $0.78^{\mathrm{NS}}$ \\
\hline Flavour & 6 & $5.68^{a} \pm 0.14$ & $5.71^{a} \pm 0.07$ & $5.36^{a} \pm 0.18$ & $1.93^{\mathrm{NS}}$ \\
\hline Texture & 6 & $5.51^{\mathrm{a}} \pm 0.12$ & $5.64^{\mathrm{a}} \pm 0.08$ & $5.22^{\mathrm{a}} \pm 0.16$ & $3.03^{\mathrm{NS}}$ \\
\hline Crispiness & 6 & $5.41^{\mathrm{ab}} \pm 0.11$ & $5.70^{b} \pm 0.07$ & $5.15^{\mathrm{a}} \pm 0.14$ & $6.01^{*}$ \\
\hline Saltiness & 6 & $5.63^{a} \pm 0.16$ & $5.67^{\mathrm{a}} \pm 0.04$ & $5.31^{\mathrm{a}} \pm 0.18$ & $1.87^{\mathrm{NS}}$ \\
\hline $\begin{array}{c}\text { Overall } \\
\text { acceptability }\end{array}$ & 6 & $5.42^{\mathrm{ab}} \pm 0.08$ & $5.64^{b} \pm 0.16$ & $5.14^{\mathrm{a}} \pm 0.09$ & $4.33^{*}$ \\
\hline
\end{tabular}

Means bearing same superscript in a row do not differ significantly $(\mathrm{P}>0.05)$

Table.4 Mean \pm SE values for physico chemical analysis of buffalo meat extruded product with optimum proportions of tapioca flour under ambient storage condition

\begin{tabular}{|c|c|c|c|c|c|c|c|}
\hline \multirow[t]{2}{*}{ Parameters } & \multicolumn{7}{|c|}{ Storage period in days } \\
\hline & $\mathbf{0}$ & 15 & 30 & 45 & 60 & 75 & 90 \\
\hline TBA No. & $\begin{array}{l}0.12^{\mathrm{a}} \\
\pm 0.01\end{array}$ & $\begin{array}{l}0.20^{\mathrm{a}} \\
\pm 0.05\end{array}$ & $\begin{array}{l}0.44^{\mathrm{ab}} \\
\pm 0.11\end{array}$ & $\begin{array}{l}0.68^{b} \\
\pm 0.09\end{array}$ & $\begin{array}{l}0.81^{b} \\
\pm 0.08\end{array}$ & $\begin{array}{l}1.18^{\mathrm{c}} \\
\pm 0.18\end{array}$ & $\begin{array}{l}1.37^{\mathrm{c}} \\
\pm 0.23\end{array}$ \\
\hline $\begin{array}{l}\text { Tyrosine } \\
\text { value }\end{array}$ & $\begin{array}{l}0.88^{\mathrm{a}} \\
\pm 0.12\end{array}$ & & $\begin{array}{l}1.38^{b} \\
\pm 0.13\end{array}$ & $\begin{array}{l}1.39^{b} \\
\pm 0.10\end{array}$ & $\begin{array}{l}1.53^{b} \\
\pm 0.12\end{array}$ & $\begin{array}{l}1.62^{b} \\
\pm 0.13\end{array}$ & $\begin{array}{l}1.73^{b} \\
\pm 0.11\end{array}$ \\
\hline Hardness (kg) & $\begin{array}{l}6.12^{\mathrm{a}} \\
\pm 0.62\end{array}$ & $\begin{array}{l}7.04^{\mathrm{a}} \\
\pm 0.96\end{array}$ & $\begin{array}{l}6.72^{a} \\
\pm 0.57\end{array}$ & $\begin{array}{l}7.59^{a} \\
\pm 0.70\end{array}$ & $\begin{array}{l}6.48^{\mathrm{a}} \\
\pm 0.49\end{array}$ & $\begin{array}{l}6.45^{\mathrm{a}} \\
\pm 0.95\end{array}$ & $\begin{array}{l}6.54^{\mathrm{a}} \\
0.77^{2}\end{array}$ \\
\hline $\begin{array}{c}\text { Fracturability } \\
(\mathbf{m m})\end{array}$ & $\begin{array}{l}10.14^{\mathrm{a}} \\
\pm 1.02\end{array}$ & $\begin{array}{l}9.74^{\mathrm{a}} \\
\pm 1.05\end{array}$ & $\begin{array}{l}9.34^{\mathrm{a}} \\
\pm 0.83\end{array}$ & $\begin{array}{l}8.48^{a} \\
\pm 0.72\end{array}$ & $\begin{array}{l}9.21^{\mathrm{a}} \\
\pm 0.68\end{array}$ & $\begin{array}{l}9.81^{a} \\
\pm 0.99\end{array}$ & $\begin{array}{l}9.18^{a} \\
\pm 0.72\end{array}$ \\
\hline
\end{tabular}

Means bearing same superscript in a row do not differ significantly $(\mathrm{P}>0.05)$

Table.5 Mean \pm SE scores for sensory evaluation of buffalo meat extruded product with optimum proportions of tapioca flour under ambient storage condition

\begin{tabular}{|c|c|c|c|c|}
\hline \multirow{2}{*}{ Parameters } & \multicolumn{4}{|c|}{ Storage period in days } \\
\cline { 2 - 5 } & $\mathbf{0}$ & $\mathbf{3 0}$ & $\mathbf{6 0}$ & $\mathbf{9 0}$ \\
\hline Appearance & $5.74^{\mathrm{a}} \pm 0.20$ & $5.61^{\mathrm{a}} \pm 0.23$ & $5.82^{\mathrm{a}} \pm 0.19$ & $5.81^{\mathrm{a}} \pm 0.11$ \\
\hline \hline Flavour & $5.54^{\mathrm{a}} \pm 0.01$ & $5.56^{\mathrm{a}} \pm 0.21$ & $5.63^{\mathrm{a}} \pm 0.31$ & $5.54^{\mathrm{a}} \pm 0.10$ \\
\hline Texture & $5.49^{\mathrm{a}} \pm 0.12$ & $5.60^{\mathrm{a}} \pm 0.26$ & $5.85^{\mathrm{ab}} \pm 0.75$ & $6.39^{\mathrm{b}} \pm 0.15$ \\
\hline Crispiness & $5.41^{\mathrm{a}} \pm 0.11$ & $5.53^{\mathrm{a}} \pm 0.08$ & $5.87^{\mathrm{ab}} \pm 0.23$ & $6.36^{\mathrm{b}} \pm 0.20$ \\
\hline Saltiness & $5.63^{\mathrm{a}} \pm 0.16$ & $5.68^{\mathrm{a}} \pm 0.18$ & $5.99^{\mathrm{ab}} \pm 0.22$ & $6.41^{\mathrm{b}} \pm 0.14$ \\
\hline Overall & $5.33^{\mathrm{a}} \pm 0.14$ & $5.46^{\mathrm{a}} \pm 0.07$ & $5.56^{\mathrm{a}} \pm 0.10$ & $5.55^{\mathrm{a}} \pm 0.10$ \\
\hline acceptability & & & & \\
\hline
\end{tabular}

Means bearing same superscript a row do not differ significantly $(\mathrm{P}>0.05)$ 


\section{Hardness (kg)}

The mean \pm S.E values of hardness of buffalo meat extruded product at optimum proportions of tapioca flour for $0,15,30,45,60,75$ and 90 days were $6.12 \pm 0.62,7.04 \pm 0.96,6.72 \pm$ $0.57,7.59 \pm 0.70,6.48 \pm 0.49,6.45 \pm 0.95$ and $6.54 \pm 0.77$ respectively. Analysis of variance revealed highly significant $(\mathrm{P}<0.01)$ difference between storage periods.

These results were in congruent with the statement of Rhee et al., (1997) who found that the beef extrudates had lower hardness values and Brncic et al., (2006) who mentioned that the increase in the feed moisture content increased the hardness in the final extrudates.

\section{Fracturability (mm)}

The mean \pm S.E values of fracturability of buffalo meat extruded product at optimum proportions of tapioca flour for $0,15,30,45$, 60,75 and 90 days were $10.14 \pm 1.02,9.74 \pm$ $1.05,9.34 \pm 0.83,8.48 \pm 0.72,9.21 \pm 0.68$, $9.81 \pm 0.99$ and $9.18 \pm 0.72$ respectively. Analysis of variance revealed highly significant $\quad(\mathrm{P}<0.01)$ difference between storage periods. The high value of fracturability for the buffalo meat extruded product prepared from the optimum proportion of tapioca flour were due to the fracture behaviour of starch used as (Luyten $e t$ al., 2004).

There was a significant increase in the thiobarbituric acid no. tyrosine value and hardness throughout the storage period but no significant difference were found in sensory evaluation hence it could be concluded that tapioca powder can be included in buffalo meat extruded product in 15:85 proportion.

\section{References}

Anna Anandh, M. V. Lakshmanan, S. K. Mendiratta, A. S. R. Anjaneyulu and
G. S. Bisht, 2005. Development and quality characteristics of extruded tripe snack food from buffalo rumen meat and corn flour. Journal of Food Science and Technology 42: 263-267.

APEDA 2014. Agricultural and Processed Food Products Export Development Authority, New Delhi, India.

Bryant, R. J., R. S. Kadan, E. T. Champagne, B. T. Vinyard and D. Boykin, 2001. Functional and Digestive Characteristics of Extruded Rice Flour. Cereal Chemists 78: 131-137.

Camire, M. E. and M. P. Dougherty, 2002. Added Phenolic Compounds Enhance Lipid Stability in Extruded Corn. Journal of Food Science 63: 516-518.

Choudhury, G. S. and A. Gautam, 2003. Hydrolyzed Fish Muscle as a Modifier of Rice Flour Extrudate Characteristics. Journal of Food Science 68: 1713-1721.

El-Samahy, S. K., E. A. Abd El-Hady, R. A. Habiba and T. E. Moussa-Ayoub, 2007. Some Functional, Chemical and Sensory Characteristics of Cactus Pear Rice-Based Extrudates. Journal of Professional Association Cactus Development 9: 136-147.

FAOSTAT 2012. FAO statistical yearbook.

Gogoi, B. K., A. J. Oswalt and G. S. Choudhury, 1996. Reverse Screw Element(s) and Feed Composition Effects during Twin Screw Extrusion of Rice Flour and Fish Muscle Blends. Journal of Food Science 61: 590-595.

Jauregui, R. N., R. A. Cardoso-Santiago, M. E. M. Pinto e Silva and J. A. G. Areas, 2003. Acceptability of snacks produced by the extrusion of amaranth and blends of chickpea and bovine lung. International Journal of Food Science and Technology 38: 795-798.

Luyton, H., J. J. Plijter and T. V. Vliet, 2004. Crispy/Crunchy crusts of cellular solid foods. A literature Review with 
discussion. Journal of Texture Studies 35: 445-492.

Mittal, P. and R. A. Lawrie, 1984. Extrusion Studies of Mixtures containing certain Meat Offals: Part 1-Objective Properties. Meat Science 10: 101-116.

Mittal, P. and R. A. Lawrie, 1986. Extrusion Studies of Mixtures containing certain Meat Offals: Part 2- Textural Properties. Meat Science 16: 143-160.

Mohamed, S. 1990. Factors Affecting Extrusion Characteristics of Expanded Starch Based Products. Journal of Food Processing and Preservation 14:
437-452.

Park, J., K. S. Rhee, M. K. Kim and K. C. Rhee, 1993. High protein texturized products of defatted soy flour, corn starch, and beef: Shelf life physical and sensory properties. Journal of Food Science 58: 21-27.

Strange, E. D., R. C. Benedict, J. L. Smith and L.E. Swift, 1977. Evaluation of rapid test for monitoring alteration in meat during storage.1. Intact storage. Journal of Food Protection 40: 843847.

\section{How to cite this article:}

Karthikeyan, S., V. Appa Rao, R. Narendra Babu and Karthika, S. 2019. Development of Ready to Eat Buffalo Meat Product using Tapioca Flour. Int.J.Curr.Microbiol.App.Sci. 8(10): 2421-2429. doi: https://doi.org/10.20546/ijcmas.2019.810.281 